\title{
Capacity Development In Realizing The Good Governance In The Era Of Regional Autonomy
}

\author{
Moris Yogia Adidi \\ Riau Islamic University \\ Pekanbaru, Indonesia \\ Email: moris.adidiy@gmail.com
}

\begin{abstract}
This paper gives an overview of the implementation of the constitution laws such as the embodiment of the political will of the Central Government, but in practice occur various obstacles. The model has become divided in 3 (three), namely: the bottleneck in the autonomous region, of good Governance and capacity building in implementing Regional Autonomy. The Government of the provinces, counties and cities should implement the values of good Governance, such as strategic vision, transparency, responsiveness, fairness, consensus, effectiveness and efficiency, accountability, freedom of Assembly and participation, rule of law, democracy, in cooperation with community organizations, our commitment to the market, and commitment to environment and decentralization. Some elements of capacity development in order to realize a good Governance can be seen from some of the items, the first development of the vision and mission of regional and provincial government institutions/district/city. Second, the institutional development of the Government of the province/district/city. Third, the development of a network of Government provincial/district/city. And fourth, the development and utilization of the environment of the Government of the province/district/city.
\end{abstract}

Keywords - capacity building, Good Governance, regional Autonomy

\section{INTRODUCTION}

Toward the Year 2000 until now, "autonomous region" much discussed by politicians, Bureaucracy, Government, Universities, the non-governmental organization most people even in General. Of course, this discussion based on "viewpoints" or otherwise can be the "importance" of each of them. Therefore there is a range of understanding of the "autonomous region" of the effect on the response spectrum and its application.

Wishes or expectations about the implementation of the regional autonomy are already implied in the 1945 Constitution Chapter IV Article 18. Government regions (provinces, counties, and cities) manage and take care of his own Government Affairs according to the principle of autonomy and help tasks. In the Interim CONSTITUTION also stated it on chapter IV Article 131, Indonesia Division over large areas and small reserves the right to take care of his hands home alone (autonomous).
In the "new order" such wishes poured into Act No. 5 of the year 1974. However, the ACT critical because the system is decentralized and autonomous region offer was considered too pompous because it is not supported by the existing resource capability (Government and society). Therefore any implementation was delayed until the area that will accept autonomy was declared ready autonomous. The attitude of the Central Government is taken as the desire of giving a half-hearted, autonomy and continue to demand that the autonomy of the region immediately given. In the end, the Central Government held a trial in some areas, but unfortunately a test autonomous region too artificial as it does not correspond to the aspirations and needs of the region, the strong influence of the Centre, and burdening the State budget and the area give rise to various problems in the area.

To accommodate the aspirations and interests of the region, the then President Habibie issued Act No. 22/1999; This ACT was judged very promising, because of more guarantees the principle of democracy, the role of society, justice and equity, as well as paying attention to the potential and diversity of the region. In the development of an increasingly pluralist society and to respond to developments that there is, in the Government of President Megawati s. p. issued Act No. 32/2004, and on the Government of President Susilo Bambang Yudhoyono issued Act No. 23/2014 on local governance.

This paper gives an overview of the implementation of the ACT as a manifestation of the political will of the Central Government, but in practice occur various obstacles. The model has become divided in 3 (three), namely: the bottleneck in the autonomous region, of good Governance and capacity building in implementing Regional Autonomy.

\section{DISCUSION}

A. Barriers to the Implementation of Regional Autonomy

The difference in concept and paradigm of autonomous region

a. The difference in concepts of autonomous region 
In the discussions of this autonomous region, there may be differences of perception among intellectuals, and bureaucratic officials, among them there is the autonomous region perceives as the principle of respect for the life of the community in accordance with indigenous history Customs and its properties in the context of a unitary State [1]. There was also autonomous region perceives as an attempt of regional Economic perspective, which provided opportunities for Westernization and for the initiative was meet his interests, so that they can appreciate and respect the community, Unity, and unity in the context of SO.

After enacted Act No. 22 of the year 1999, Act No. 32 the year 2004 and Act No. 23 of the year 2014, the reaction from various parties vary considerably, as a result of the differences in interpretation of the term autonomy. There are groups that interpret as autonomous independence or freedom in all matters at once into the right area. Those who have this perception usually leery of the Central Government, the autonomous region is regarded as the independence of the region from the shackles of the Central Government.

There are other groups which interpret as granting "authority authority" in taking decisions in accordance with the interests and aspirations of local communities. Here are perceived or construed as an autonomous Division of authority, meaning that autonomy as authorities, autonomous regions (district/city to arrange and take care of his affairs on the basis of the aspirations of the community. His form is the classification authority to the region in all areas of Government, except in the fields of defense and security, judicial, fiscal and monetary, foreign religious and political authority as well as other fields such as national planning, control of national development, changes to the financial system, the administration of the State and the institutions of the State economy, coaching and empowering human resources, utilization of natural resources and strategic high technology, conservation and National standardization.

There are also groups that interpret the autonomous region as a mechanism of empowerment (empowerment). According to the Group interpreting autonomy should accommodate various local interests and local institutions and authorities needed for it. So it's taken a special deal in the Division of tasks/between which are handled by the Central Government and local governments.

The autonomy concept interpretation of variation due to the difference in theoretical references. Theoretically, the term "autonomy" has many meanings and then raises a wide range of interpretation.

Further in (Price and Mueller, 1986:40) expressed that Autonomy is also interpreting as "The Degree to Wich and Organization Has Power with Respects to Its Environment." In this case to distinguish between government organizations and business. Power here interpreted as "influence" or "supervision". In this context regional autonomy interpreted as to how far a local government control to local community interests fulfillment activities regardless of the influence of the environment. [2].

Another meaning is also expressed by Dworkin (1995: Terry 49) as a situation where the community to create and organize your own constitutions. Of course, this is based on the meaning of the word "auto" which means me and "nomos" meaning the rule of law. [3] With the meaning of this autonomous region can be interpreted as a selfregulating authority or independence. A description of the concept of autonomy over extremely variable such as freedom and independence, the Organization's strategy, the authority to take care of yourself, take your own decisions, the power to conduct surveillance, empowerment, and selfsufficiency in the settings themselves. A variation of this concept gives rise to diverse interpretations. Therefore in the future needs to be an agreement on the concept of regional autonomy among the political elite as a top policy decisionmaking.

b. The difference the paradigm of the autonomous region

Variations of the above meanings are associated also with the major paradigm in relation to the autonomy that is the political and organizational paradigm of the clash.

According to paradigm the political autonomy of public bureaucracy, there can be no and will not be developed due to the political interests of the lower-level regime in making your own decisions. Local government (regency, city) is subordinate Government Center, and theoretically the subordination and autonomy contradicts, therefore according to the paradigm of politics, autonomy cannot run for the position of an institution is subordinated from higher institutions.

Unlike the political paradigm, the paradigm of an organization just shows how important the "autonomy" to guarantee the qualities bureaucracy is desirable. To guarantee the quality of bureaucracy then initiative, breakthrough, innovation, and creativity should be developed in this regard will be obtained when the bureaucratic institutions that have an autonomy. In other words, the paradigm of "organization" see that there should be an autonomous bureaucracy that one can grow and develop and maintain the quality so as to provide the best for the community.

The second paradigm above is correct. The autonomy necessary for an organization to be able to grow and develop and maintain its existence and integrity, but "autonomy" is also difficult because the regional bureaucracy is sub-ordination Center (State) bureaucracies. Therefore a compromise must be found in order for such autonomy had walked. The response to both the above paradigm advanced by Terry $(1995 ; 52)$, which recommends that autonomy should be seen in the paradigm of "contextual", i.e. linking autonomy with the prevailing political system and the needs of the Community area. 
Therefore, in the context of the autonomy in Indonesia should be seen also as an attempt of keeping unity and unity on one side and the other side as a bureaucratic effort to respond to Indonesia diversity Indonesia in order to be able to provide the best services for the community.

The ACT. No. 22 The Year 1999, Act No. 32 The Year 2004 and Act No. 23 of the year 2014 is embraced this paradigm, using the approach of "Authority". It can be seen from the meanings of "autonomy" as the authorities of the autonomous regions (regency/city) to arrange and take care of the interests of the local community according to its own initiative on the basis of the aspirations of the community in accordance with the legislation in the context of a unitary State of INDONESIA. It is very right, but in the case of Indonesia in the perspective of the realities, because less autonomous region issue is not just a question of sheer authority but a lot of things that are related to the resources and the existing infrastructure, in the area is still very weak.

\section{c. Strong bureaucratic paradigm}

Until now the local government authorities have not dared to do the needed breakthrough. In the framework of the implementation of regional autonomy and to provide the best service for the community because it is still the strong influence of the bureaucratic paradigm. This paradigm is characterized by a highly structured organization based hierarchical with a high degree of differentiation, disperse authority central and high formalization (standards, procedures, and strict rules).

In practice in Indonesia, the determination of hierarchy and Division of organizational units, standards, procedures and rules the region largely determined by the Central Government, and local governments must be loyal towards those rules. In the field of management has been prepared by the Central Government, various guidelines, instructions in handling various tasks service and construction in the area. In the field of public policies, programs and projects as well as the activities of the proposed activity subject to the approval of the Central Government. Its implications are still many officials in the area to await orders and instructions from the Center. This implementation of the bureaucratic paradigm has been built for so long and deep and even become "personalities" some key at institution regional government apparatus. It needs to be done to reform the public administration in the region, leaving the old paradigm of weaknesses, and learn, understand and adopt new paradigms such as "Post Bureaucratic" (see Barzelay, 1992) or "Reinventing Government, "1992, 1997). [4].

d. Weak supervision of representatives of the people and the community
For not less than 32-year new order regime came to power, the role of the representatives of the people in control of the Executive is not very effective, since co-opted by an elite executive. The bureaucracy in the region tend to serve the interests of the Central Government, serving the interests of local communities. Surveillance against a bureaucratic apparatus by the legislature and the public seem artificial and democratic fesudo. This weakness we realize together, the changes have been done immediately after the turn of the new order regime to order reforms. Political and autonomous region ACT came into force, the spirit and the process of democracy are promising, and surveillance against the bureaucracy began although sometimes too much. Pity the spirit of democracy is arising and developing these reform regions not followed by a strategy of increased capabilities and qualities representatives of the people. Representatives of people who are still capable of doing their jobless to control against Government. This inability to provide opportunities for executives to act freely and otherwise inconsequential expense Act legislative interest the public who believed to represent his interests.

\section{e. Error strategy}

Laws on local governance implemented at a regional government that is weak. Local governments were given authority to do for themselves what they need, but with a very marginal capability. This is due to the domination of Central Government in regions is too excessive, and less role and provide learning opportunities for the region. Development model made during the implementation of this very bureaucratic with the result in the collection of the creativity of local government and its officials.

More than that, unpreparedness and an inability of the areas that used to be used as a reason for delaying autonomy less cared for. But to realize the autonomous region is a problem that complexity high and can cause various problems such as the emergence of a conflict between the local community with his Government, and it can be a very bad impact on the integrity of the Government institutions both at or at the region. At least six things to note in the context of the implementation of this autonomous region namely does not artificially ripened preparation, giving confidence, clarity of vision, the readiness resources, and various parameters on performance demands.

\section{B. Good Governance in Implementing Regional Autonomy}

In the implementation of the policy of regional autonomy, one of the disadvantages faced by the performance assessment is a standard Government, theoretical orientation of paradigmatic leads to a classic bureaucratic manner that prioritizes (means) than goals (ends). Should this autonomous region in the era of the 
orientation of government performance follow a paradigm reinventing government or bureaucratic post which give priority to performance on the end result or purpose of a vision of the Organization and not on the gets input and runs the process (see Osborne and Gaebler, 1992). At this time the demands will be a good Governance in this increasingly urgent to accommodate in the standard assessment of the performance of the Government. [5].

The concept of good Governance when traced farther from the writings of KJ. S. Edralin (1947) [6]. Where "governance" is the terminology that is used to replace the "government", this term describes the changing role Government from service (providers) to the "enabler or the facilitator "and change the ownership of the State belong to the people. The focus of the attention of good governance is improved performance and improved quality. At the beginning of "good governance" promoted by some multilateral organizations such as OECD, JICE, GTZ in 1991, and then by the United Nations and the agencies under the United Nations (UNDP). These institutions create an indicator of good governance (good Governance), indicators as indicated in table 1 . All of the indicators are good, but in the context of Indonesia will be better to wear indicators are complete. These indicators can be used to measure up to how far institutions and local government apparatus (Province/County/City) has been realizing the values of good Governance in the real and perceived by the public. As for the values of good Governance, among others:

\section{1) Strategic Vision}

The Government of the province, district and City should have a clear vision and mission.

2) Transparency

The Government of the province, district and city provide information to the public so that the public can be openly questioned why a decision is made, what criteria are used so that the community can conduct surveillance, monitor performance public institutions.

3) Responsiveness

The Government of the provinces, counties, and Cities must be responsive to the problems, needs, and aspirations of the communities that they serve.

4) Justice

The Government of the provinces, counties, and Cities should be able to give everyone the same chance to improve or repair the welfare.

5) Consensus

The Government of the provinces, counties, and Cities should be able to play a role in bridging the community in order to reach a mutual agreement in the interest of the community.

6) Effectiveness and efficiency

The Government of the provinces, counties, and Cities are required to be able to meet the needs of the community, by utilizing resources in a good way or through the management of the sector that is effective and efficient.

7) Accountability

The Government of the provinces, counties, and Cities should be accountable to the public in the context of the performance of the institutions and the authorities both in the field of management, organization, and public policy.

8) Freedom of Assembly and participate

The Government of the provinces, counties, and Cities may provide a space for freedom to its people to assemble, organize and participate actively in determining its future.

9) Law Enforcement

The Government of the provinces, counties, and Cities can create and enforce rules of law that make up the situation and conditions of safe and orderly as well as conducive to the community.

10) Democracy

The Government of the provinces, counties, and Cities may encourage democratic processes in society.

11) Cooperation with community organization.

The Government of the provinces, counties, and Cities can embody the cooperation with the Community institutions have in solving the problems in the service to the public.

12) Commitment to the market

The Government of the provinces, counties, and Cities are able to encourage policies oriented to the market.

13) Commitment to the environment

The Government of the provinces, counties, and Cities are able to pay attention to issues related to environmental sustainability.

14) Decentralized

The Government of the provinces, counties, and Cities are able to develop and cultivate local institutional units in order to take public policy suitable for the local situation and needs.

When the values can be implemented by the Government of the province, district, and city in the Organization of the autonomous region, then the welfare society will be realized. But to be able to immediately realize it, then the need for a change of mindset, attitudes and patterns of follow-up the bureaucrats from the old bureaucratic orientation to a new bureaucracy as orientation values. In order for a pattern of attitudes, mindsets, and pattern of acts subject to change, then the change required a system of national provincial, Regency and city proper according to the needs of local communities.

Law No. 23 of the year 2014 is a very important momentum in the national history of Indonesia, although there are still some weaknesses to realize. These weaknesses need to be improved as we do capacity building to support the good Governance which in turn support the holding of 
regional autonomy in the form of autonomous empowered and independent.

\section{Capacity Development in Realizing the Good Governance in the Autonomous Region.}

As explained above that since the enactment of the law on local governance, more technical considerations in deciding things. The assumption that the area has been prepared or has been able to be less wise. If you want to be honest we actually not ready for autonomous, because it has not been equality of perception against the concept and paradigm of the autonomous region, strong bureaucratic paradigm, the capacity of representatives of the people who have not been adequate, and error strategy. Therefore, although Act No. 23-year 2014 have been put in place there are still many among the less optimistic in making it happen because the preparation is not yet mature.

In the context of a contextual paradigm, the autonomous region should allow local governments are able to provide the best for the people of the region in the framework of the unitary State of INDONESIA.

Although the two things to realize is not an easy job. The demands of this new contextual paradigm can be met when local governments and LEGISLATORS have the ability. As a first step to do is to capacity development as recommended in the framework of improving local governance (see Grindle, 1997; Fiszbein, 1997; Edralin, 1997; Mentz, 1997; and Eade, 1998) towards a good Governance. With the development of this capacity, we will be able to accelerate the attainment of, a good Governance in the era of the autonomous region, which boils down to harmony the life of the nation, state, and society as well as to achieve prosperity, security, and order of society. [7].

\section{a. Understanding capacity development}

Capacity development for governance is defined as potentially experiencing unplanned strategy aimed at improving the efficiency, effectiveness, and responsiveness of governance performance, by concentrating the attention to the development dimension human resources, strengthening the Organization, and institutional reform or environmental Grindle (1997:5). In this definition of capacity development contained attempts to make improvements in the quality of human resources, encouraging organizations to function better, and change the context of the environment required HUMAN RESOURCE organizations and individuals in order to function properly.

From a variety of literature can be collected a few dimensions of capacity development for governance, among others, the development of human resources (see Fiszbein, 1997; Grindle, 1997; World Bank in Edralin, 1997), strengthening of the Organization and management (see Grindle, 1997; Fiszbein, 1997; [8] Eade, 1998; Mentz, 1997; [9]. United Nations in Edralin, 1997), provision of resources, facilities and infrastructure (see the UNDP in Edralin, 1997; Fiszbein, 1997), network (see Eade, 1998; World Bank in Edralin, 1997), the environment (see World Bank in Edralin, 1997; Grindle, 1997). And the mandate, programs, and fiscal capability (see United Nations in Edralin, 1997).

Based on an understanding of the literature, then to realize an autonomous region in the current moment is required preparation in every sector. All the elements that should be developed or improved above should be seen as a unity of a system, which if addressed that one can affect the other. These elements pertaining to the ability of the Government in the provision of inputs (all the resources it needs), process (the application of appropriate techniques and methods), feedback (input and process improvement), and environment (creation of situation and a conducive condition).

\section{b. elements of capacity development}

Until now there hasn't been any clarity regarding the development of Government institutions and regional vision and District/city. District/city government's vision is unclear, so there has been no clarity about the strategic areas that may be developed in the region in order to achieve that vision. Therefore, at the moment that is required is the development of (1) the regional strategic plan district/city, and (2) the Government institution's strategic plan for District/city.

Strategic areas that should be developed within the institutional development plan of strategic Government largely determine the type and range of annual policy (in programs and activities), the type and the number and quality of institutions the Government is required, the types and levels of managerial abilities required include the type of leadership, and a system of public accountability as well as the organizational culture of Government. In other words, institutional improvements should be based on the needs of the development of the strategic areas that have been formulated in the plan of the regional government institutions and strategies provinces, regencies, and cities. Thus, it needs to be done in the institutional development include (1) policy development, (2) development of the Organization, (3) development of management, (4) the development of a system of public accountability, and (5) developing the culture of the organization.

Strategic areas in the above strategic plan should also specify the type, amount, and quality of human resources required in the region particularly on provincial government institutions/district/city.

The strategic plan has given the direction of the human resources and institutional development that exist in the area. In the development of the various regions certainly, have different limitations. Because it must be made possible the process of self-study and collaboration with other parties 
and should not be with the Central Government as long as it happens. Should in the future area of freedom to learn from each other or learn (1) provinces, districts or other cities both from within and from abroad, and (2) the vertical institutions that exist, and (3) development centers like College and NGOs that suits their needs, through a network of planned work. The collaboration between them is very helpful learning fast in the area.

Besides all the fixes and improvements to the above, the Government of the region urgently needs an environment that is conducive, which from him can be utilized to do the best for the region. Here area should be sought (1) utilization of physical and non-physical environment optimally and liable, (2) the utilization of higher legal regulations and (3) the creation and maintenance of security and order in the area. Regulatory legislation that supports local development should be utilized while security and public order must be created and utilized for construction and public services in the region. In this context, the region should maintain, perpetuate and exploit their surroundings in order to make the community feel secure in order to provide service to the community.

\section{CONCLUSION}

The Organization of regional autonomy in Indonesia has gone through a fairly long process, where we can see a variety of advancement as well as weaknesses in its implementation. This is something a reasonable thing that must be traversed in the holding of nation and State. The Government of the province, district and city institutions involved directly and has a very strategic role in realizing successful or whether the Organization of the autonomous community.

The Government of the provinces, counties and cities should implement the values of good Governance, such as strategic vision, transparency, responsiveness, fairness, consensus, effectiveness and efficiency, accountability, freedom of Assembly and participate, law enforcement, democracy, in cooperation with community organizations, our commitment to the market, and commitment to environment and decentralization.

Some elements of capacity development in order to realize a good Governance is as follows:

1) The development of the vision and mission of regional and provincial government institutions/district/city.

2) Institutional development of the Government of the province/district/city.

3) Development network of Government provincial/district/city.

4) Development and utilization of the environment of the Government of the province/district/city.

\section{REFERENCE}

[1] Abdullah,H.R, Pelaksanaan Otonomi Luas dan Isu Federalisme Sebagai Suatu Alternatif. Jakarta : PT. Raja Grafindo, 2000.

[2] Price,J.L, and C.W Mueller, Handbook of Organizational Measurement, Marshfield, MA. Longman, 1986.

[3] Terry, L.D, Leadership of Public Bureaucracies: the administrator as conservator. London: Sage Publications, International Education an Professional Publiser, 1995.

[4] Barzelay,M, Breaking Through Bureucracy: new vision for managing in government.LA University of California Press, 1992.

[5] Eade.D, Capacity Buliding: An Approuch to people-centered development. Oxford, UK Oxfam,GB, 1998.

[6] Edralin.J.S, The new local governance and capacity building: A strategic approuch. Regional Development Studies. Vol 3, 1997.

[7] Fiszbein, A, The emergence of local capacity : Lesson from Columbia. World Development Vol.25(7), hal 1029-1043, 1997.

[8] Grindle,M.S (Editor), Getting Good Government: Capacity Building in the Public Sectors of Developing Countries. Boston, MA: Havard Institute for International Development, 1997.

[9] Linerick,D.dan B.Cunnington, Managing the New Organization: A Blueprint for network and strategic alliances. West chatsood NSW: Business \& profesional Pubhlishing, 1993.

[10] Mentz, J.C.N, Personal and Institutional Factors in Capacity Building and institutional development. Working Paper No. 14 Maastrict: ECDPM, 1997.

[11] Osborne, D. And Gaebler.T, Reinventing Governmen. Reading MA: Addison Wesley Longman Inc, 1992. 